\title{
19 Conclusions on the Latin used in scientific texts
}

\$1 The computational results from the previous chapter can now be compared with the observations about the language used in scientific communication assembled in part 2 of this book. Through its long and varied history, Latin has known many different styles and registers. In Antiquity, for instance, we can speak of Ciceronian, 'bombastic' (see chap. 8 §11), or Christian Latin. Besides many individual registers and styles, the Latin Middle Ages developed its own kind of Latin koine, ${ }^{1}$ which, though different from classical standards to some extent, still had its own relatively fixed and stable standards, first described in detail by Stotz (1996-2004). Its syntax and vocabulary have more in common with Late Antiquity with a good dose of Christian Latin, than with Classical Latin. In the Middle Ages, some special types of Latin, such as Hiberno-Latin or scholastic Latin, are easy to discern too. In early modern times, humanist Latin contrasts with more pragmatic Latin. Those are but a few examples. Approaches to science have also changed significantly in the two thousand years reviewed in part 2. We found seven epochs. In some of them, language and approaches seem to have remained quite constant (the time of the artes liberales, university science, Scientific Revolution); those in between were rather more diverse (Roman Antiquity, twelfth century, Renaissance). Some attempts to group scientific Latin texts on the basis of all the data we have so far encountered are now presented: based on the last and apparently most convincing PCA plot (\$2), on Latin style (\$3), and on Greek scientific models (\$4). Typical example texts are then presented and analysed (\$§5-6). The discussion of differences that are due to scientific topics is postponed to chapter $20 \S 8$.

\$2 The numbers and plots in chapter 18 have shown that some of these rather crude grammatical parameters distinguish surprisingly well between scientific and non-scientific Latin prose. But, as expected, it has also become clear that there is no linear development of scientific prose through time, because Latin is a language with a very good memory. So, quite in general within Latin it has always been possible to imitate older authors, and traditionalists who are against all novelty were always on hand to rein in new developments. Nonetheless, there are also new norms being developed over time. The data above have produced the following candidates (from left to right in fig. 38).

- The 'scholastic type', including neo-scholastic authors such as Suárez and (less clearly) Boyer, forms a clearly defined group. High numbers: ADV, N,

1 As Chiesa (2017) puts it.

Ә Open Access. ( 2021 Philipp Roelli, published by De Gruyter. (c) BY Creative Commons Attribution 4.0 International License.

https://doi.org/10.1515/9783110745832-020 
PREP, IND, ESSE, REL, modifiers; very low: V; low: 1st SG. Similar, often even more extreme, numbers were found for the next type.

- The 'Greek translator type', including the translations of De interpretatione and Liber de causis, and that by Argyropoulos. Very high: modifiers; high: ADV, CONJ, PRON, IND, NOM; low: N, V, GEN, ADJ-SUF, N-SUF. Some translators have high numbers of PTC (Greek uses them a lot), some seem to avoid them consciously. The humanist translator Ficino does not fit into this group.

- The 'encyclopaedic-technical type', Pliny, Vitruvius, Isidore, Bede, Rabanus. Low: PRON, ADV, INF, CONJ:S; (relatively) high: N, PTC, entropy.

- 'Scientific Revolution, natural sciences': Copernicus, Vesalius, Descartes, Galileo, Newton form a not very clearly defined group in our data. Low: N-SUF, ESSE, modifiers (all three can be seen as influences of humanism); less low: V; low: NOM. The arithmetic sample used in chapter 20 clusters between these texts and the scholastic ones.

- 'Scientific Revolution, human sciences' or 'modern academic Latin': Vossius, Kircher, Kretschmann, sometimes the historiography sample and the charters. These texts are even less clearly defined; they are not too far removed from the non-scientific benchmark samples. Relatively high: PTC, ABL, entropy; often high numbers of ABL ABS.

- The 'antique type' (Cicero, Seneca). Low: SUF, esp. N-SUF; high: ABL ABS; in general staying close to non-scientific Latin. The sample of scientific poetry from chapter 20 groups quite close to these prose texts in the plot. But this seems to be an artefact: it is more the case that these texts mix features from non-scientific poetry (even further to the right in the plot) and from scientific prose texts, which will explain their position. Typical values go with normal poetry (low: CONJ, PREP, SUB, GEN; high: N, PTC), a few with the average for the scientific texts (1st SG, POSS; 3rd PAS in between).

- A 'juridical type' (Gaius, Pauli sententiae, Digesta) also remaining relatively close to the non-scientific benchmark can be postulated. Low: ADJ; high: INF, ABL/DAT; low numbers for ADJ-SUF but high ones for N-SUF. Two out of three of these texts also have low ADV, high CONJ, and high numbers of ABL ABS. In general, it seems that juridical language in Antiquity was quite varied: the three texts in the sample usually do not cluster very closely together.

The similarity between scholastic and Greek translation texts does not come as a surprise: after all, the scholastic type can be said to begin with Boethius' translations of Aristotelian Greek. Interestingly, the above groups fit in quite well with the following epochs treated in part 2: university science (chap. 11), twelfth-century translators (chap. 10), artes liberales (chap. 9), two types corresponding to the Scientific Revolution (chap.13), and two to Roman science (chap. 7). Non- 
translating authors from the twelfth century (Abelard, Anselm, Guilelmus de Conchis, Hugh of St Victor), as well as those of the Renaissance (Cardano, Copernicus, Vesalius, the translator Ficino) do not exhibit similar traits among one another (they were already found to be rather heterogeneous in part 2 above). Some authors seem to have quite their own type of Latin: Varro, Apuleius, Tertullian, and Lullus can be mentioned. Of course, some authors also fall rather in between such groups; for instance, Cardano sometimes goes with the tentative encyclopaedic-technical type, sometimes with the natural science type, or Vossius is often atypical for the modern human science group.

\$3 Part 2 has shown some rather clearly disparate stylistic approaches among the authors treated, unrelated to their scientific approaches. The following ones seem to be deductible from our texts. ${ }^{2}$ The list is arranged chronologically by first exponents; examples below (\$4) will provide more concrete data.

(i) 'Hexametric'. A 'scientific poetry' text sample that will be very different from the rest of the sampled texts will be studied further in the next chapter. Lucretius decisively shaped the form and style of didactic and scientific Latin poetry. The hexameter is mostly used, but this kind of didactic poetry clearly differs from other genres using it (such as the epic). The hexametric approach became mostly didactic after an initial phase in which leading scientific innovation was communicated in it in Greek by authors such as Parmenides and Empedocles (see chap. 7 $\S 2)$.

(ii) 'Rhetorical'. A rhetorical approach to presenting scientific material can be said to have been the standard approach in Roman Antiquity. The Latin rôle model was certainly Cicero; authors such as Seneca, Quintilian, or Augustine followed, as well as some historiographers. These authors were especially intent on teaching the reader dialectically. Didactic dialogues are common, and new words are avoided. This way of writing tends to remain rather close to non-technical Latin, as an orator will not wish to put off his audience with, for instance, unusual terminology. The concern for the beauty of the text sometimes seems to outweigh that for scientific precision. Humanists strove to return to such a style, but it remained rather rare among scientific writers due to its obvious disadvantages in precision and flexibility; still, there are some writers using it in all epochs, for instance Vesalius in the sixteenth century, but after the twelfth century this style was mostly confined to popular science. In Greek a similar approach was used by Plato (chap. $7 \S 4$ ).

2 Greek-translation Latin is not considered here as it is not genuinely Latin, although it influenced scholastic Latin decidedly. 
(iii) 'Plain'. The first surviving, and most important, author for what might be called plain, unrhetorical, matter-of-fact scientific Latin is Pliny. Later technical and encyclopaedic writers sometimes use similar Latin (Vitruvius to some extent, Isidore, Bede, Rabanus). This plain approach toward language, concentrating fully on the scientific content, may be seen as especially fit for the task. However, later scientists will realise that clear and deliberately employed syntax and wellchosen vocabulary are important for conveying difficult content: the plain approach was, therefore, largely superseded by the more technical and Hellenised scholastic approach after the advent of the universities in the thirteenth century, although some later encyclopaedic authors such as Cardano use a similar approach again. A Greek model can be seen in Alexandrian technical tracts, for instance grammatical ones. Below (chap. 21 and table 22), it will be seen that 'medical Latin' is a special subgroup of this approach. Quite similar to that of Pliny, it represents the language of a more practical science. Among medical writers, Celsus may be rather atypical, as he hardly used Greek terms and did not coin Latin ones frequently; later authors are quite free with new terminology.

(iv) 'Bombastic'. Some scientific authors have used bombastic Latin since the second century, for instance some neo-Platonists such as (in some works) Apuleius or Martianus Capella, especially in his mythological framework, among early Christians especially Tertullian. Their unusual bombast can be concentrated in their vocabulary or consist of complicated and often ambiguous syntax; in addition, there are metaphors, wordplays, and lots of words from Greek and possibly from other old and venerable languages. All of this produces a rather hermetic and inaccessible Latin, and remained rather the predilection of a few scientific writers. Its innovative vocabulary reminds one of Democritus (chap. 7 §2).

(v) 'Scholastic'. A scholastic approach could be clearly seen emerging during the twelfth century, although it had a conspicuous predecessor in Boethius, especially in his second Porphyry commentary. This language is very much logically structured, it contains many new coinings, often from Aristotle's translated Greek, and tries to keep them unambiguous, thus relying strongly on Aristotle's lecture style (chap. 7 §5). This kind of language is syntactically straightforward and not afraid to coin new terms; both these points serve the aim of making things clearer. In contrast to the encyclopaedic type, there is a special emphasis on logical stringency. This will be the most innovative type of Latin for the sciences, and the most important one. Typical authors used in our sample were Aquinas, Albertus, Duns, Ockham, and in some respects even more the translations from the Greek of the Liber de causis and De interpretatione. Neo-scholastics may have been somewhat less daring in their language, but the approach clearly remains the same (Suárez, Boyer). This is the first Latin approach to language that would seem to correspond to a Greek scientific Denkstil in being rigorous and yet flexible enough for science. 
Users of both the rhetorical and the mathematical types attacked its capacity to support empty disputation and its 'ugliness'. It is indebted to Aristotle.

(vi) 'Mathematical'. The Greek rôle model of this approach is clearly Euclid. As there is no extant Euclid translation before the twelfth century, such texts tend to appear late in Latin: Copernicus, Kepler, Newton, and many of the texts in the arithmetic sample studied in the next chapter. Structuring of the content into theorems, proofs, and the like is typical for it; the texts are often accompanied by tables, charts, figures, and formulas. The syntax is simple but rigorous; there is a conspicuous technical vocabulary. In general, it can be said to be a formulaic type of language (see chap. 22, §4). The language obviously changes with the increasing formalisation of mathematics. Newton may be the best-known, typical representative of an advanced state of this type of language. It would seem to be the ancestor of today's vernacular language of the mathematical natural sciences.

(vii) 'Modern academic'. It would seem that only toward Latin's demise in the seventeenth and eighteenth centuries does there seem to arise a consensus about what scholarly Latin is supposed to look like. A kind of mixture of the scholastic and the mathematical approaches, here and there with a pinch of rhetoric, apparently became standard in the less mathematical sciences. On the one hand, this language does strive for grammatical correctness according to classical rules, and to avoid excesses in word formation (unlike the bombastic and scholastic styles), but rhetorical syntactic excesses are also avoided and the rhetorical disdain for nova verba is given up. Greek loanwords, in particular, are frequent. Typical authors were Vossius, Kircher, and Kretschmann, or countless dissertations from the seventeenth to the nineteenth centuries (not included in our samples). This academic style may be the most pragmatic scientific Latin. It could have served very well as an international auxiliary for scientific communication. This seems to be a genuine Latin approach; there does not seem to be a Greek model for it.

This list of types of scientific Latin will not be exhaustive: some authors and some fields would deserve their own labels and would require further study. In some cases, it is conspicuous that there is no typical approach in some groups of writers. This is especially the case for juridical Latin, which does not seem to be homogeneous, and there is neither a clear 'humanist' or early modern approach in science, nor a single Jesuit approach: Boscovich wrote, despite his mathematical topic, a rather rhetorical Latin, Boyer a clearly neo-scholastic one, others normal modern academic Latin (such as Orlandini; see chap. 20). It would seem that these approaches correspond to Denkstile concerning the relation between language and knowledge. This will be further pursued when discussing examples below. 
These styles of rendering science in the Latin language fit in quite well with the computationally determined language styles listed above (§2); only the bombastic style proves hard to make out clearly. Various early modern and late academic styles are also hard to discern. ${ }^{3}$ In the time of the Scientific Revolution, it was more and more the case that only two styles remained valid for serious science: the mathematical and the modern academic ones. ${ }^{4}$ Indeed, an ever more perceptible differentiation between mathematical and human sciences in the times of the Scientific Revolution seems to become apparent. Unfortunately, very few such late academic Latin texts have been digitised yet. It would be interesting to study a sample of such texts separately. The number of available digital texts will become much larger with the completion of the Noscemus project (Innsbruck).

All but the last of these Latin scientific styles can be linked to Greek models. The single most important factor in the development of Latin as a language of scientific communication was certainly influence from Greek, providing new vocabulary and often also affecting syntax and textual grammar, not to mention its obvious epistemic input in most sciences. The three Greek models producing the most successful approaches to language used in science stem from Plato, Aristotle, and Euclid. These correspond roughly to the rhetorical, scholastic, and mathematical approaches in the list above. This classification and its ways of dealing with words for new things are further explored below (chap. 21). The importing of science from Greek into Latin will be pursued below (chap. 24 §5).

\$4 There is no doubt that technical vocabulary and syntax are the two most conspicuously different aspects of scientific language. In extreme cases, single words may already be indicative of a particular type of language. The PREP secundum all by itself can act as a marker for scholastic texts: its frequency in the general corpora is on average $0.87 \pm 0.51 \%$; the following texts from our sample use it more than 3 stdevs more: Ficino (2.45), Boethius 2 (2.46), Boyer (2.50), Suárez (2.75), De interpretatione (3.22), De causis (4.87), Ockham (3.84), Abelard (7.11), Roger Bacon (4.32), Duns (7.14), Aquinas (7.48), Albertus (8.78) - precisely the scholastic authors. Interestingly, the less scholastic first commentary of Boethius ('Boethius 1') hardly uses it (0.15). However, in later times this ceases to be a very good marker, as writers after the Renaissance were aware that this is an 'ugly' scholastic word and may have consciously avoided it. In order to corroborate and illustrate the seven approaches of scientific Latin identified above (§3), a typical sample of each is now presented and analysed in terms of some of the more conspicuous

3 In both cases, having more available data might change the picture.

4 And in some 'neo-scholastic' fields also the scholastic approach (chap. 11 §8). 
features encountered above: technical vocabulary, ${ }^{5}$ especially formed by the suffixes considered above (chap. 18 §2), Greek loanwords, syntactic nexuses (shown by highlighting linking conjunctions and adverbs), MODIFIERs, the newn, and the verb esse, besides parameters that were noted to be rare in scientific Latin (chap. 18): first person and possessive pronouns. Texts involving the Moon in some way or other were chosen to illustrate the types of Latin, by authors who seem especially typical for each approach. All the authors have been encountered above in part 2.

(i) Lucretius V.705-736, ed. Ernout, vol. 2, p. 76. This passages discusses explanations of the lunar phases.

Luna potest solis $\underline{\text { radiis }}$ percussa nitere inque dies magis $<$ hoc $>$ lumen conuertere nobis ad speciem, quantum solis secedit ab orbi, donique eum contra pleno bene lumine fulsit atque oriens obitus eius super edita uidit; inde minutatim retro quasi condere lumen debet item, quanto propius iam solis ad ignem labitur ex alia signorum parte per orbem; ut faciunt, lunam qui fingunt esse pilai consimilem, cursusque uiam sub sole tenere. Est etiam quare proprio cum lumine possit $\underline{\text { uoluier, }}$ et uarias splendoris reddere formas. Corpus ENIM licet esse aliud fertur, et una labitur, omnimodis occursans officiensque, nec potis est cerni, quia cassum lumine fertur. Versarique potest, globus ut, si forte, pilai dimidia ex parti candenti lumine tinctus, uersandoque globum uariantis edere formas, donique eam partem, quaecumque est ignibus aucta, ad speciem uertit nobis oculosque patentis; inde minutatim retro contorquet, et aufert luciferam partem glomeraminis atque pilai; ut Babylonica Chaldaeum doctrina refutans astrologorum artem contra conuincere tendit, proinde quasi id fieri nequeat pugnat uterque, aut minus hoc illo sit cur amplectier ausis.

DENIQUE cur nequeat semper noua luna creari ordine formarum certo certisque figuris, inque dies priuos aborisci quaeque creata atque alia illius reparari in parte locoque, difficilest ratione docere et uincere uerbis, ordine cum «uideas tam certo multa creari.
705 It may be that the Moon shines hit by the Sun's rays and day by day she turns this light more toward us to see, the more she recedes from the Sun's orb, until facing him opposite she shines in full light and coming up rising on high has seen his setting;

710 then by and by she must as it were hide her light again, the more she glides closer to the Sun's fire from other parts of the zodiac on her orbit. This is what those hold who conceive her similar to a ball and to have her course beneath the Sun. There

715 is also the possibility that she rotates with her own light, producing different aspects of her splendour. For another body may exist that moves and is gliding with her, always running along and blocking her, yet not discernible as being devoid of light.

720 It may also be that she rotate like a globe, if perchance one half be painted in glistening light, and by rotating the globe she produce her aspects, until she turns that part which is all filled with light visible for our sight and our open eyes; then by and by it turns to the back and increases the luminous part of the globe or ball.

This is what the Babylonian teaching of the Chaldeans sets out, refuting the astronomers' art. Just as if what the two fight for could not coexist: why should one more than the other be embraced? Moreover, why should not a new Moon be created in a fixed order of aspects and in certain forms, each of them every day created to perish, and to be replaced by another one in her place and stead? as you see many things produced in a fixed order.

5 To qualify, a term must be used in a different way than in everyday Latin. Of course, there are uncertain cases. 
Quite typically for his approach, the author is of the opinion that one should not try to evaluate the relative quality of different proposed scientific hypotheses (730), although he presents several of them. ${ }^{6}$ By his time, there was no longer any doubt among Greek intellectuals that the first 'hypothesis' is the correct one. Technical vocabulary is rare, and all terms will have been understandable to the non-astronomer. In contrast, poetic figures such as synonyms are used (glomeramen - pila - globus), as well as hendiadys (in parte locoque); some rare poetic language is also used (aborisco, only here in CC; donique for donec). The syntax is not always clear (e.g. where does super in 709 belong?). All linguistic features highlighted in the text are very rare compared to the other samples.

(ii) Cicero, De re publica I.14(21-22), ed. Ziegler, pp. 14-15. The description of the Syracusan heavenly globe is presented. Before this passage, the observation of two suns was discussed.

Tum Philus: 'nihil novi vobis adferam, neque quod a me sit ‘ex〉cogitatum aut inventum; NAM memoria teneo C. Sulpicium Gallum, doctissimum ut scitis hominem, cum idem hoc visum diceretur et esset casu apud M. Marcellum, cum eo consul fuerat, sphaeram Marcelli avus captis Syracusis ex urbe locupletissima atque ornatissima sustulisset, cum aliud nihil ex tanta praeda domum suam deportavisset, iussisse proferri; cuius ego sphaerae cum persaepe propter Archimedi gloriam nomen audissem, speciem ipsam non sum tanto opere admiratus; erat ENIM illa venustior et nobilior in volgus, ab eodem Archimede factam posuerat in templo Virtutis Marcellus idem. sed posteaquam coepit rationem huius operis scientissime Gallus exponere, plus in illo Siculo ingenii quam videretur natura humana ferre potuisse iudicavi fuisse. dicebat ENIM Gallus sphaerae illius alterius solidae atque plenae vetus esse inventum, et eam a Thalete Milesio primum esse tornatam, post AUTEм ab Eudoxo Cnidio, discipulo ut ferebat Platonis, eandem illam astris caelo inhaererent, esse descriptam; cuius omnem ornatum et descriptionem sumptam ab Eudoxo multis annis post non astrologiae scientia sed poetica quadam facultate versibus Aratum extulisse. hос аутем sphaerae genus, in quo solis et lunae motus inessent et earum quinque stellarum quae errantes et quasi vagae nominarentur, in illa sphaera solida non potuisse finiri, atque in eo
Then Philus said: 'I shall not report to you anything new that was thought up or invented by myself. But I remember that when this same phenomenon [two suns] was reported, Gaius Sulpicius Gallus - as you know a very learned man - happened to be with M. Marcellus, who was consul with him; he ordered the sphere to be placed before him that Marcellus' grandfather had brought home from the wealthy and embellished town of the vanquished Syracusans, the only thing he had brought home from so much booty. I had often heard of this sphere because of the fame of Archimedes, but I did not so much admire its construction, for another one, which Marcellus had deposited in the temple of Virtue, also made by Archimedes, was in the general view more elegant and noble. But when Gallus began to explain the mechanism of this work in a very learned way, I judged that there was more ingenuity in that Sicilian than seemed possible in human nature. For Gallus said the other solid and full sphere was an old invention, first wrought by Thales of Miletus, then adorned by Eudoxus of Cnidus - as he said, a disciple of Plato - with the stars that are fixed in the sky. And that all its adornment and its description was taken from Eudoxus, was made public many years later in the verses of Aratus not with the knowledge of an astronomer but with a certain poetic agility. On this type of solid sphere, however, the Sun, the Moon and the five so-called wandering or rambling stars

6 An interesting point of contact between Epicureanism and postmodernism. 
admirandum esse inventum Archimedi, excogitasset quem ad modum in dissimillimis motibus inaequabiles et varios cursus servaret una conversio. hanc sphaeram Gallus cum moveret, fiebat ut soli luna totidem conversionibus in aere illo quot diebus in ipso caelo succederet, ex et in [caelo] sphaera solis fieret eadem illa defectio et incideret luna tum in eam metam, esset umbra terrae, cum sol e regione «lacuna». could not be included; in this lay the admirable invention of Archimedes, who thought out, the movements being dissimilar, how a single revolution could produce the unequal and varied courses. When Gallus moved this sphere, it happened that the Moon followed the Sun with as many revolutions in that brass as it took the real sky days; by this the same eclipse of the Sun happened on the sphere and the Moon fell into the same point that marked the shadow of the Earth, when the Sun from the region [...].

The work is a dialogue and therefore makes frequent use of the first person singular. There is hardly any technical vocabulary and hardly any Greek terminology, but the syntax is complicated and digressions are frequent (for instance here on the qualities of Aratus). The scientific details of how the sphere worked are not provided (probably not in the missing text either). The hendiadys errantes et quasi vagae is intended to render $\pi \lambda \alpha$ ávi $\tau \varsigma$; later Latin will loan the word as planetae (as most modern languages do). ${ }^{7}$ ESSE, REL, and modifiers are rather frequent, betraying Greek influence.

(iii) Pliny, Naturalis historia II.6(44-46), ed. Ernout et al., vol. 2, pp. 20-21. A passage on the movement of the Moon and its rôle in astronomical discoveries in the past.

Proxima ERGo cardini, ideoque minimo ambitu, uicenis diebus septenisque et tertia diei parte peragit spatia eadem, Saturni sidus altissimum XXX, ut dictum, annis. Dein morata in coitu solis biduo, cum tardissime, a tricesima luce rursum ad easdem uices exit, haud scio an omnium, in caelo pernosci potuerunt, magistra: in XII mensium spatia oportere diuidi annum, quando ipsa totiens solem redeuntem ad principia consequitur:solis fulgore reliqua siderum regi, siquidem in totum mutuata ab eo luce fulgere, qualem in repercussu aquae uolitare conspicimus: ideo molliore et inperfecta ui soluere tantum umorem atque etiam augere, quem solis radii absumant; ideo inaequali lumine adspici, quia, ex aduerso demum plena, reliquis diebus tantum ex se terris ostendat quantum a sole ipsa concipiat; in coitu QUIDEM non cerni,
[The Moon] is closest to the cardinal point of the universe, thus it has the shortest orbit, in $271 / 3$ days it traverses the same space that Saturn, the highest planet, does in thirty years, as has been said. Then after two days of conjunction with the Sun, on the thirtieth day at the latest she returns to the same place; she may well be the teacher of all heavenly phenomena that can be known:

- that it is proper to divide the year into the twelve spaces of months, when she reaches the Sun who has returned to the beginning [of his orbit] as many times, - that the other stars are controlled by the Sun's splendour, shining forth in reflected light from him, which we see flutter as if reflected in water; thus, by the Moon's softer and imperfect force water can only be dissolved or augmented, whereas the Sun's rays consume it, thus she is seen in unequal light as she is full when opposite, the other days she shows the Earth only as much of herself as she receives from the Sun,

7 But note Icelandic reikistjarna ('roaming star'). 
quoniam haustum omnem lucis auersa illo regerat, unde acceperit; - sidera UERo haud dubie umore terreno pasci, quia dimidio orbe numquam maculoso cernatur, scilicet nondum suppetente ad hauriendum ultra iusta $\underline{\text { ui; }}$ masculas ЕNIM non aliud esse quam terrae raptas cum umore sordes; - defectus AUTEM suos et solis, rem in tota contemplatione naturae maxime miram et ostento similem, magnitudinem umbraeque indices exsistere. but in conjunction she cannot be discerned as she turns back all collected light toward whence it came, - that the stars without doubt are nourished by earthly water, as when half full she is never seen spotted, that is, the force is not yet sufficient to draw more than its share: the spots are thus nothing else than dragged off earth with watery filth, - that her eclipses and those of the Sun are the greatest miracles in the observation of nature and similar to what is shown: pointers of the size and the shadow.

Paratactic infinitive clauses list pieces of information we have, apparently, learned thanks to the Moon. ${ }^{8}$ The resulting syntax is not simple; the entire excerpt consists of only two sentences, but it looks carelessly composed, rather like a list; the logical nexuses between the idea that the Moon has taught us all we know about the heavens and the individual items seem to get lost toward the end. The technical details are wanting, but technical vocabulary is used consistently, though sparingly. The marked linguistic features are all relatively rare. Although this type of language is not rhetorical, it would not seem to be very technical either.

(iv) Martianus Capella, De nuptiis Mercurii et Philologiae VIII, §§862-864, ed. Willis, pp. 326-327. On the illumination of the Moon, thus the same topic as in the Lucretius sample. The scientific approach is now that of the Greek communis opinio.

Nunc iam Lunae meatum, quae terrae propinquior est, uideamus. Quam QUIDEM menstruum habere lumen physicorum assertione persuasum est; cum sit, semper pleni orbis esse non dubium est. NAM si ab illa parte, se subicit Soli, omni hemisphaerio conlustratur, etiam cum nobis tricesima nullum lumen ostendit, superne, Solem spectat, pleno lumine relucescit; denique cum discedens a Sole a latere eum coeperit intueri, pro parte etiam inferius lumen adquirit, donec e regione posita ab hac parte, nobis est uisibilis, collustretur. Circuit ENIM eius globum undiquesecus Solis nitor et ei parti, totam tunc aspicit, lumen indulget, cuius luminis radii in terras quoque tlucubrandioret perueniunt, ut si quis e speculo lumine repercusso effigiem lucis excipiat. QUIDEM LUna cum eum in orientis partibus comprehenderit, obscuratur, et cum in occasu
Now let us take a look at the course of the Moon, which is closest to the Earth. Her monthly changing light was convincingly explained by natural enquiry. If it is so, there is no doubt that there is always a full circle. For on the part which faces the Sun a full hemisphere is illuminated, even when she shows us no light on the thirtieth day when she looks toward the Sun, she shines forth in full light above. Moreover, when she parts from the Sun she begins to look at him from the side, partly she receives light below until she gets positioned in the region in which she is visible to us, and is fully illuminated. The Sun's lustre then has moved around her globe and grants light to that full part that one can see, his rays then arrive on Earth also in more nightly shifts, ${ }^{9}$ as when someone becomes aware of a form of light on a

8 Of these four 'observations', three are still believed today.

9 This would seem to be the meaning of this passage. Willis puts it in cruces desperationis. 
deseruerit, lucescit. Cuius primi luminis effigies

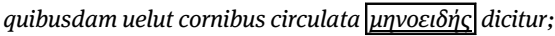
cUm UERO XC partibus a Sole discedens orbem eius

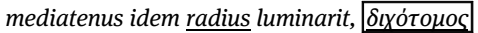
perhibetur, sed praedictis partibus cum alias XLV

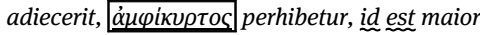
dimidia, minor plena; cum UERO CLXXX partibus a Sole discesserit, contrario posita totam partem, terris opponit, illuminans $\pi \alpha v \sigma \dot{\lambda} \lambda \eta v$ s perhibetur; ac dehinc deficiens seruat cum praedictis partibus nomina memorata. QUIDEM XIII orbis sui partes die nocteque transcurrit, cum pro latitudine circulorum, obeunt, eodem interstitio Mars dimidiam, Iuppiter duodecimam unius partis, Saturnus uicesimam octauam unius portionis excurrat. mirror reflecting light. One that, when the Moon apprehends it when he is still rising, is dim, but when met during his setting, shines forth. Her first likeness of light, pointy as if with horns, is

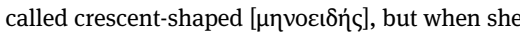
recedes $90^{\circ}$ from the Sun, half of her circle is

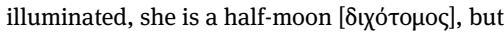
when you add to the mentioned ones another $45^{\circ}$,

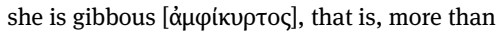
half, less than full. But when she is $180^{\circ}$ from the Sun, posited in opposition, the entire part facing toward the Earth illuminated, she is a full-moon

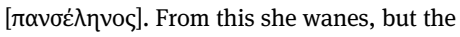
mentioned names are used again. She traverses $13^{\circ}$ of her orbit in 24 hours, whereas due to the amplitude of the orbits they follow, in the same time Mars traverses $0.5^{\circ}$, Jupiter $0.08^{\circ}$, Saturn $0.036^{\circ}$.

A few Greek terms are used in the text, some unusual Latin ones (lucubrandior, mediatenus), complicated syntax, and a lot of sentence-modifying particles. All the marked features are relatively common, except suffixes. Martianus is fond of using poetical and metaphorical meanings of words ('the Moon is looked at by the Sun'); rhetorical variatio is common. It would seem that depending on his source, Martianus used technical terminology sometimes abundantly, sometimes hardly at all. He often intersperses his Latin with Greek words. It takes the reader a while to understand that the complicated sentence beginning with Quae quidem Luna presupposes the moment when the Moon rises over the horizon: if then the Sun is setting, the Moon is full and bright, if the Sun is still rising, the Moon is not yet full and less bright. ${ }^{10}$ This is scientifically quite a trivial statement, wrapped in a very complicated, bombastic sentence. This approach is typical for Martianus, whose language looks more like an intricate and hermetic artwork for connoisseurs than matter-of-fact science.

(v) Albertus Magnus, De caelo et mundo I.1.11, ed. Hossfeld, vol. 5.1, p. 29. Albertus comments and explains Aristotle's cosmology in De caelo; quite typically, he often also analyses problems not directly mentioned in the Aristotelian text in this case, whether the heavenly bodies can be said to suffer change.

10 Several printed translations misunderstand this point. 
Est АUтем adhuc observandum, quod cum dicitur, quod caelum non alteratur, intelligitur de alteratione physica. Est ENIM quaedam alteratio non est motus, sed finis motus, fit subito per illuminationem et per lumen, est forma prima corporis luminosi, quia videmus bene, luna alteratur secundum hoc. Et nos etiam inferius ostendemus, quod omnis stella praeter solem sic alteratur, nec est instantia contra determinata, quod inveniuntur stellae frigidae et calidae et umidae et siccae, quia hoc dicitur de stellis per causam, quia talia efficiunt in inferioribus per naturam sui luminis, emittunt, et non disponuntur talibus qualitatibus. Et huius probatio est, quia, sicut nos in octavo physicorum probavimus, quod omnis motor secundum locum reduci et resolvi habet ad motorem primum, est immobilis secundum locum et simpliciter, ita necesse est, quod omne movens in alteratione reducatur ad unum alterans et non dispositum aliqua qualitate formaliter alterante; aliter ENIM primum factivum qualitatum alterantium esset factivum per accidens. Si ENIM diceretur, quod calor non sit nisi per motum et frigiditas per distantiam a motu, cum motus non faciat calorem nisi per accidens, non haberemus in natura substantiale et primum movens in alteratione, et hoc est inconveniens, quia secundum hoc primae qualitates, commiscent omnia et distinguunt elementa, essent per accidens et per consequens omnia fierent ex ipsis, essent per accidens et non per intentionem naturae.
It is besides to be observed that when it is said that the heavens do not change, ${ }^{11}$ this is understood in terms of physical alteration. For there is a kind of alteration that is not movement but the end of movement that happens immediately by illumination and by light which is the first form of a luminous body, as we see well that the Moon changes according to it. And we shall show below that every heavenly body except the Sun changes in this way; it is no objection against what is known: that some heavenly bodies are cold, some hot, some wet, some dry, because this is said of what the heavenly bodies cause, as they act among things down here by the nature of the light they emit, but they do not dispose of such qualities. And the proof of this is that, because as we have proven in the eighth book of the Physics $^{12}$ that every mover according to space has to be attributable and resolvable to the first mover, who is immobile according to space as well as absolutely, therefore it is necessary that everything that moves be attributed in alteration to something that alters it and that does not dispose of any formally altering quality, for otherwise the first agent of altering qualities altered by accident. For if it is said that heat exists only through motion and cold by the absence of motion, as motion produces heat only by accident, we would not have in nature a substantial and first mover in alteration, which is unsuitable, as according to this the first qualities which mix everything and distinguish the elements, would exist by accident and consequently everything that arises out of them would exist by accident and not by nature's intention.

The vocabulary is very technical, much more so than in the previous four samples. Logical nexuses are given much weight; they are unambiguous. Nominalised participles (movens, alterans) are used in a Greek way. Linking conjunctions are very common, especially the typically scholastic quia and quod, as well as the relative pronoun. In fact, all the marked features are common. Aristotelian vocabulary pervades the text. Potential subjunctives may also be noted as common in this passage.

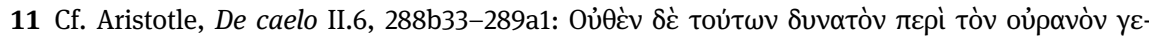

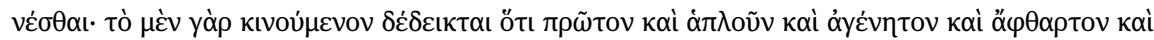
ő $\lambda \omega \varsigma \dot{\alpha} \mu \varepsilon \tau \dot{\alpha} \beta \lambda \eta \tau$ Tov ('Nothing of these things may happen to the sky. It has been shown that what is moved is primary, simple, uncreated, imperishable, and generally unchangeable').

12 Cf. De physica VIII.2.9, ed. Borgnet, vol. 3, pp. 588b-589a. 
(vi) Newton, Principia mathematica III, prop. V. theor. V. (Londini, 1687 edition, p. 407). About the Jupiter moons.

\author{
Planetas circumioviales gravitare in Iovem, \& \\ circumsolares in Solem, \& vi gravitatis suae \\ $\underline{\text { retrahi semper a motibus rectilineis, \& in orbibus }}$ \\ curvilineis retineri. \\ NAM revolutiones Planetarum circumiovialium \\ circa Iovem, \& Mercurii ac Veneris reliquorumque \\ circumsolarium circa Solem sunt Phaenomena \\ eiusdem generis cum revolutione Lunae circa \\ Terram; \& propterea per Hypoth. II. a causis \\ eiusdem generis dependent: praesertim cum \\ demonstratum sit quod vires, a ruibus revolutiones \\ illae dependent, respiciant centra Iovis ac Solis, \& \\ recedendo a Iove \& Sole decrescant eadem ratione \\ ac lege, vis gravitatis decrescit in recessu a \\ Terra. \\ Corol. 1. Igitur gravitas datur in Planetas \\ universos. Nam Venerem, Mercurium caeterosque \\ esse corpora eiusdem generis cum Iove nemo \\ dubitat. CERTE Planeta Hugenianus, eodem \\ argumento Satellites Iovis gravitant in Iovem, \\ gravis est in Saturnum. Et cum attractio omnis (per \\ motus legem tertiam) mutua sit, Saturnus vicissim \\ gravitabit in Planetam Hugenianum. Eodem \\ argumento Iupiter in Satellites suos omnes, \\ Terraque in Lunam, \& Sol in Planetas omnes \\ primarios gravitabit. \\ Corol. 2. Gravitatem, quae Planetam unumquem- \\ que respicit, esse reciproce ut quadratum distantiae \\ locorum ab ipsius centro.
}

\begin{abstract}
That the Jupiter moons gravitate around Jupiter, the planets around the Sun, and that they are drawn off continuously from rectilinear motion by their gravitational force and retained in curvilinear orbits. For the revolutions of the Jupiter moons around Jupiter and those of Mercury, Venus, and the other planets around the Sun are phenomena of the same kind as that of the Moon around the Earth, and therefore according to hypothesis $\mathrm{II}^{13}$ depend on causes of the same genus, especially as it was shown that the forces on which the revolutions depend, tend to the centres of Jupiter or the Sun, and that they decrease in the same ratio and according to the same law receding from Jupiter or the Sun as the gravitational force decreases when receding from the Earth.

Corollary 1. Therefore, gravity acts on all planets, for no one doubts that Mercury, Venus, and the others are bodies of the same kind as Jupiter. Certainly, Huygens's planet [Titan] gravitates on Saturn by the same argument as the Jupiter satellites do on Jupiter. And as every attraction is mutual (by the third law of motion), ${ }^{14}$ Saturn also gravitates toward Huygens's planet. By the same argument, Jupiter will gravitate toward all its moons, the Earth toward the Moon, and the Sun toward all primary planets.

Corollary 2 . The gravity that concerns any planet is to the inverse square of the distance of the places from its centre.
\end{abstract}

The theorem is stated as an independent accusativus cum infinitivo; it is then proved from what had been said before. The language is full of technical terms, often (though not here) including mathematical formulas, proofs, geometric diagrams. There are many Latin true compounds (circumiovialis, circumsolaris, curvilineus, rectilineus) in this passage, although this may not be very typical in general. The recently discovered Saturn moon Titan is called planeta Hugenianus after its discoverer, Christiaan Huygens. Syntactically the text is concise and clear but not conspicuous; the other highlighted features are common.

13 At the beginning of book III (p. 402), hypothesis II was stated as: Ideoque effectuum naturalium eiusdem generis eaedem sunt causae ('Therefore the causes of natural effects of the same kind are the same').

14 Treated in I, prop. III, theor. III, p. 39. 
(vii) Vossius, Ars historica 6 (Lugduni, 1653 edition, pp. 32-33). On the invention of historiography and the Arcadians, who are said to be older than the Moon.

Longè vERò alia ratio historiae est. inventrix Clio dicitur Apollonii scholiastae 1 in

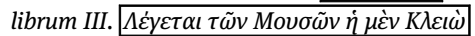

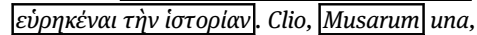
historiam invaenisse fertur. Inventionem Cadmo Milesio tribuit Plinius lib. VII. cap. LVI. etiam loco Pherecydem Syrium scribit primùm prosam condidisse. At lib. V cap. XXIX id ipsum etiam Cadmo tribuit, alios, puto, secutus autores. Sed et Strabo lib. I tradit, Hecataeum cum Cadmo et Pherecyde metrum solvisse, ac primos prorsam instituisse orationem, eâque de re adeunda quoque Suidae collectanea. Nos apud Graecos hos fuisse historiae autores, haut inficias imus: at $\underline{\dot{\alpha} \pi \lambda \tilde{\omega} s}$ si intelligant, Mosen longè antiquiorem historicum agnoscimus. Quin \& eum historiae conditorem putat Eusebius lib. XI. de praepar. Euang. Atque, ut id non esset, Aegyptiis potiùs haec laus deberetur, quàm Graecis: ita compellat Tatianus initio

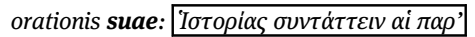

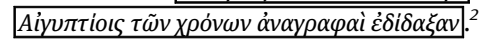
Aegyptiorum CERTE, Chaldaeorumque sacerdotes diu ante Graecos antiquitatis fuerunt studiosi. quamquam quod jactitant se conscriptas habuisse historias multorum annorum millium, id non magis verum est, quàm quod Arcades (ut scribit Statius Papinius) fuerint astris Lunâque priores, uti gloriabantur; $\pi \rho 0 \sigma \varepsilon \lambda \eta \dot{v} \omega v$ nomen à populis finitimis inditum, quòd nihil serii ante novilunium aut plenilunium aggrederentur, interpretatione sua eludentes, atque ad gentis originem referentes: nisi malis cum Censorino, ${ }^{3}$ id nomen accepisse, quòd priùs habuerint annum, quàm is in Graeciâ ad Lunae cursum constitueretur.
There is indeed a very different foundation of history. Its inventor is said to be Clio, according to Apollonius'

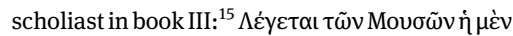

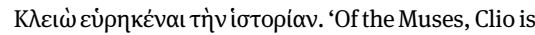
said to have discovered history'. Pliny in book VII, chapter $56^{16}$ attributed the discovery to the Milesian Cadmus, where he also writes that Pherecydes the Syrian first established prose writing. But he attributes this same feat also to Cadmus in book V, chapter 29, following, I think, other sources. But also Strabo passes on that Hecataeus together with Cadmus and Pherecydes overcame metre and established prose writing; about this very matter the Suda collection has to be consulted. We do not disown that these were the founders of historiography among the Greeks, but if understood simply, we acknowledge Moses to have been a much earlier historian. Indeed Eusebius, $D e$ praeparatione evangelica book IX, holds him to be the founder of history. And, if this were not so, this glory rather belonged to the Egyptians than to the Greeks, whom Tatian ${ }^{17}$ addresses at the beginning of his

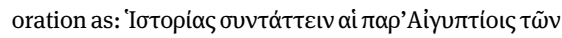

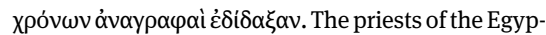
tians and the Babylonians were certainly students of Antiquity long before the Greeks, although their proclamation of having written the history of many thousand years is not more true than that the Arcadians were (as Statius Papinius writes) 'older than the stars and the Moon', ${ }^{18}$ as they prided themselves. They were given the name ‘before the Moon' by their neighbouring peoples, because they undertook nothing serious before a new moon or a full moon, they parried this with their own interpretation linking the name to their people's origin; unless you prefer with Censorinus to derive this name 'from the fact that they had a year constituted by the Moon's course before that of Greece'.

15 Cf. Scholia in Apollonii Rhodii Argonautica, ed. Wendel, p. 215: 'it is said that of the Muses Clio invented history.'

16 Naturalis historia VII.56(118), ed. Ernout et al., vol. 7, p. 205.

17 Oratio ad Graecos I.1, ed. Goodspeed, p. 268: 'the writing down of temporal events by the Egyptians taught [you Greeks] the composition of history books.'

18 Cf. Statius, Thebais IV.275, ed. Klotz \& Klinnert, p. 128. 
Notae:

${ }^{1}$ pag. 197.

${ }^{2}$ Historiam scribere Aegyptiorum annales docuerunt.

${ }^{3}$ De die natali, cap. 19.
Footnotes:

${ }^{1}$ Page 197.

${ }^{2}$ Writings of the Egyptians taught the composition of history.

${ }^{3}$ De die natali 19.

This text looks like a modern text of the human sciences, complete with footnotes and references; the sources are quite precisely quoted. The quality of sources is evaluated in a similar manner to scholasticism, but the resulting text is much less strictly and uniformly structured. The vocabulary is not very technical, but it usually quotes Greek without translation. Subordination is common, but the relative pronoun is not, and the other marked features are also not very plentiful quite in contrast to the passage from Newton. On the whole, this is a pragmatic and clear form of academic Latin, except for some very rhetorical interspersed passages.

Table 15: Pertinent values for these texts, copied from tables 11, 13, and 17.

\begin{tabular}{l|r|r|r|r|r|r|r|r|r|r|r|r}
\hline & ESSE & REL & CONJ:S & $\begin{array}{r}\text { PRON: } \\
\text { POSS }\end{array}$ & 1st SG & $\begin{array}{r}\text { 3rd } \\
\text { PAS }\end{array}$ & $\begin{array}{r}\text { ADJ- } \\
\text { SUF }\end{array}$ & N-SUF & Modifiers & $\begin{array}{r}\text { ABL } \\
\text { ABS }\end{array}$ & Entropy & $\begin{array}{r}\text { Word } \\
\text { length }\end{array}$ \\
\hline Lucretius & $\underline{2.55}$ & 3.27 & 3.09 & $\underline{0.53}$ & 2.13 & 7.67 & 0.73 & $\underline{0.60}$ & 1.38 & $\underline{4.61}$ & 9.66 & 5.58 \\
\hline Cicero & $\underline{4.73}$ & 4.81 & 3.30 & $\underline{0.58}$ & 4.88 & 10.04 & 1.27 & 2.77 & $\underline{2.78}$ & 2.34 & 9.09 & 5.69 \\
\hline Pliny & $\underline{2.12}$ & 2.49 & 1.71 & $\underline{0.31}$ & 1.23 & $\underline{13.56}$ & $\underline{1.93}$ & $\underline{2.26}$ & 0.84 & $\underline{7.81}$ & $\underline{10.38}$ & 6.04 \\
\hline Martianus & $\underline{5.49}$ & 3.71 & 2.54 & $\underline{0.23}$ & 1.54 & $\underline{16.99}$ & $\underline{0.41}$ & $\underline{1.84}$ & 2.56 & $\underline{1.59}$ & 9.84 & 5.64 \\
\hline Albertus & $\underline{6.74}$ & 5.09 & 2.41 & $\underline{0.35}$ & 0.46 & $\underline{16.84}$ & $\underline{3.05}$ & 4.86 & $\underline{2.73}$ & $\underline{0.75}$ & $\underline{8.19}$ & 5.95 \\
\hline Newton & 3.91 & 2.61 & 3.85 & $\underline{0.39}$ & 2.97 & $\underline{16.51}$ & $\underline{2.29}$ & 4.78 & 1.26 & 3.26 & 8.57 & 5.84 \\
\hline Vossius & 3.45 & 4.30 & 2.89 & $\underline{0.65}$ & 3.11 & 8.80 & $\underline{1.84}$ & 3.75 & 1.52 & 1.86 & 9.26 & 6.08 \\
\hline
\end{tabular}

\$5 The numerical values pertinent here are repeated in a single table for these seven typical authors (table 15). ${ }^{19}$ It is interesting to note that Cicero, Martianus, and Albertus share a predilection for ESSE, REL, and modifiers, although one might be tempted to see these three authors as representing the most incommensurable Latin scientific style ideals. On the other hand, suffixation may be a better indicator of technical Latin: Pliny, Albertus, Newton, and Vossius have high numbers. Low numbers for possessive pronouns and (to a lesser degree) the first person sin-

19 In the case of Albertus, another work was used as De caelo is not available digitally; for Martianus, data from another book (on arithmetic, presented in the next chapter) were used. 
gular seem to be typical for all of these scientific types of Latin, as do high numbers for the third person passive, except in scientific poetry, which certainly differs most conspicuously from the rest. Low, or at least not high, entropy values may also be typical of technical scientific writing.

When reading these texts, it becomes obvious how greatly the language of science used before and after the twelfth century differs both in content and in form. Before, practically exclusively popular and practical science is found in Latin; in contrast, the three later registers ('scholastic', 'mathematical', 'modern academic') are vehicles for theoretical science written by specialists for specialists. These types of scientific Latin are rather general. The results could probably be refined by including samples from specific sciences; historiography and medicine, in particular, would be interesting. Some forays along these lines are attempted in the next chapter. 